\title{
Subsurface algal blooms of the northwestern Arabian Sea
}

\author{
Sergey A. Piontkovski ${ }^{1, *}$, Bastien Y. Queste ${ }^{2}$, Khalid A. Al-Hashmi ${ }^{1}$, \\ Aisha Al-Shaaibi ${ }^{1}$, Yulia V. Bryantseva ${ }^{3}$, Elena A. Popova ${ }^{4}$ \\ ${ }^{1}$ College of Agricultural and Marine Sciences, Sultan Qaboos University, PO Box 34, Al-Khod 123, Sultanate of Oman \\ ${ }^{2}$ Centre for Ocean and Atmospheric Sciences, University of East Anglia, Norwich NR4 7TJ, UK \\ ${ }^{3}$ M.G. Kholodny Institute of Botany, 2 Terechenkovskaya Str., Kiev 01030, Ukraine \\ ${ }^{4}$ Institute of Marine Biological Research, 2 Nakhimov Prospect, P.O. Box 229011, Russia
}

\begin{abstract}
In situ plankton sampling, combined with remotely sensed and ocean Seaglider observations, provided insight into the termination of the winter monsoon bloom and subsequent evolution into a subsurface fluorescence maximum in the northwestern Arabian Sea. This subsurface maximum gradually descended, presenting increased fluorescence between 25 and $55 \mathrm{~m}$ depth during the spring inter-monsoon season. Species diversity decreased by half within the deep fluorescence maximum relative to the bloom. The dinoflagellate Noctiluca scintillans dominated by biomass in all samples collected from the depth of the subsurface fluorescence maximum. We show that the subsurface algal bloom persists throughout inter-monsoon seasons, linking algal blooms initiated during the southwest and northeast monsoons. In situ samples showed a net decrease in Noctiluca cell size, illustrating a shift towards a deep chlorophyll maximum adapted community, but did not exhibit any increases in chlorophyll-containing endosymbionts. We propose that the plankton biomass and estimates of the northwestern Arabian Sea productivity are much greater than estimated previously through remote sensing observations, due to the persistence, intensity and vertical extent of the deep chlorophyll maximum which using remote means - can only be estimated, but not measured.
\end{abstract}

KEY WORDS: Algal blooms $\cdot$ Chlorophyll $a \cdot$ Zooplankton

\section{INTRODUCTION}

It is generally believed that algal blooms in the Arabian Sea undergo a well pronounced seasonal cycle, governed by reversing monsoon and intermonsoon seasons (Sawant \& Madhupratap 1996, Wiggert et al. 2005, Lévy et al. 2007). The winter (northeast) monsoon affects the region from December to March, while the summer (southwest) monsoon develops from June to September. Time ranges between monsoons are called the intermonsoon seasons, although both monsoon and inter-monsoon seasons are subject to interannual variations. In the above cited and many other studies, remotely sensed chlorophyll a (chl a) concen-

\footnotetext{
${ }^{*}$ Corresponding author: spiontkovski@gmail.com
}

trations are used as an indicator of algal blooms. This seasonal variability in phytoplankton biomass is accompanied by a strong spatial heterogeneity on a basin scale. The highest seasonal means and interseasonal variability of $\mathrm{chl} a$ were observed in the western and northwestern Arabian Sea (Piontkovski \& Claereboudt 2012).

Unlike the satellite record, which now provides ocean colour-based chl a estimates over the last 2 decades, there is a paucity of in situ chl a measurements in the western Arabian Sea, and even more so in the gulf region north of Oman. This is principally due to a reduced observational effort linked to the absence of oceanographic research vessels (in Oman) designated for regular field surveys along

() The authors 2017. Open Access under Creative Commons by Attribution Licence. Use, distribution and reproduction are unrestricted. Authors and original publication must be credited. 
the Omani shelf as well as piracy issues in the western Arabian Sea region limiting access by foreign vessels.

The phytoplankton community of the western Arabian Sea is very diverse. The coastal region harbours about 287 species (Al Hashmi et al. 2015). Al-Azri et al. (2007) described the onset and development of Noctiluca blooms, the dominant phytoplankton species by biomass, in the Gulf of Oman; the study performed throughout 2005 and 2006 found that the highest concentrations of $N$. scintillans in surface waters along the coast of Muscat, Oman, occurred during the northeast monsoon (December to February). Green N. scintillans blooms were also sampled in Pakistani waters during a 5 yr period (Chaghtai \& Saifullah 2006). Farther to the east, blooms of green Noctiluca have been reported in coastal waters of India (Padmakumar et al. 2010, Madhu et al. 2012). In 2006, a regular monthly sampling programme was initiated to sample the coastal water of Oman and has characterised the community composition and phenology of coastal blooms in the region (Al-Hashmi et al. 2015).

N. scintillans is an unarmoured phagotrophic dinoflagellate which does not contain pigments and whose cytoplasm appears colourless (Dwivedi et al. 2012, Thibodeau et al. 2014). Cells are large in size, ranging from 200 to $2000 \mu \mathrm{m}$. Two forms of $N$. scintillans have been reported in the Arabian Sea: a 'red' and a 'green' variant. The latter contains the photosynthetic symbiotic alga Pedinomonas noctilucae. This green form is mixotrophic and can survive without an external food supply via photosynthetic products from its symbionts, while the red Noctiluca is heterotrophic (Harrison et al. 2011).

To better quantify the seasonal cycle of primary production in the western Arabian Sea, studies now need to focus on understanding the vertical structure of Noctiluca blooms (Gomes et al. 2008). Here we present the first season-long, high-resolution continuous observations of the vertical structure of chl a fluorescence profiles using ocean gliders (Seagliders). These data are combined with plankton sampling (with special reference to the subsurface algal bloom) and remote sensing. Chl a fluorescence is converted into chl a concentration (using coefficients from Morel \& Maritorena 2001). The use of the Morel coefficients aligns the glider and remote sensing estimates of chl a. Remotely sensed chl $a$ is a major constituent in algorithms that link remotely sensed ocean colour to primary productivity of the ocean (Saba et al. 2011).

\section{MATERIALS AND METHODS}

\author{
Plankton sampling
}

Phyto- and mesozooplankton samples were collected during the daytime (09:00-12:00 h), from the surface and at the deep chlorophyll maximum (DCM) using both 51 Niskin bottles and $150 \mu \mathrm{m}$ mesh Bongo nets. Noctiluca abundance was determined by direct count in triplicate $100 \mu \mathrm{l}$ samples collected by Bongo net and analysed by using a Zeiss inverted microscope (model 'Axiovent 25', 50× and 100× magnification). Noctiluca cells were also counted in the Niskin bottle samples collected from the deep fluorescence maximum. The Niskin bottle preserved samples were used to characterise the taxonomic composition of the phytoplankton community. In low-abundance samples, the entire sample was screened and all cells were counted. Images for optical determination of cell diameter, cell surface area, endosymbiont algal surface area and food vacuole abundance in Noctiluca were collected using a Zeiss AxioCam MRc5, and a total of 664 cells were analysed with AxioVision (v.4.8).

Mesozooplankton samples collected by nets were transferred to 0.51 bottles and preserved in $5 \%$ borate-buffered formaldehyde. Organisms were identified to the genus level and if possible to species level, then counted under a stereomicroscope.

\section{Glider observations}

A Kongsberg Seaglider 1KA (Eriksen et al. 2001) was deployed $5 \mathrm{~km}$ off the coast of Muscat and sent along a repeat transect extending $80 \mathrm{~km}$ to the northnortheast (Fig. 1). The Seaglider collected a total of 1424 vertical profiles over a period of $91 \mathrm{~d}$ (4 March to 3 June 2015), covering 24 repeats of the transect. The glider was equipped with a Seabird free-flushing conductivity-temperature sensor, a Biospherical QSP2150 PAR (photosynthetically active radiation) sensor, an Aanderaa 4330F oxygen optode and a Wetlabs Triplet ECO puck measuring chl a fluorescence $(470 / 695 \mathrm{~nm})$. Glider data were processed using the UEA Seaglider toolbox (www.bitbucket.org/bastien queste/uea-seaglider-toolbox) as per Queste (2014). The Aanderaa 4330F probe suffered from water ingress and stopped functioning on 30 April 2015, but all other sensors functioned as expected.

The Wetlabs Triplet ECO puck functions by measuring the $\sim 2 \%$ energy emitted as fluorescence during photosynthesis. The sensors emit light in the blue 

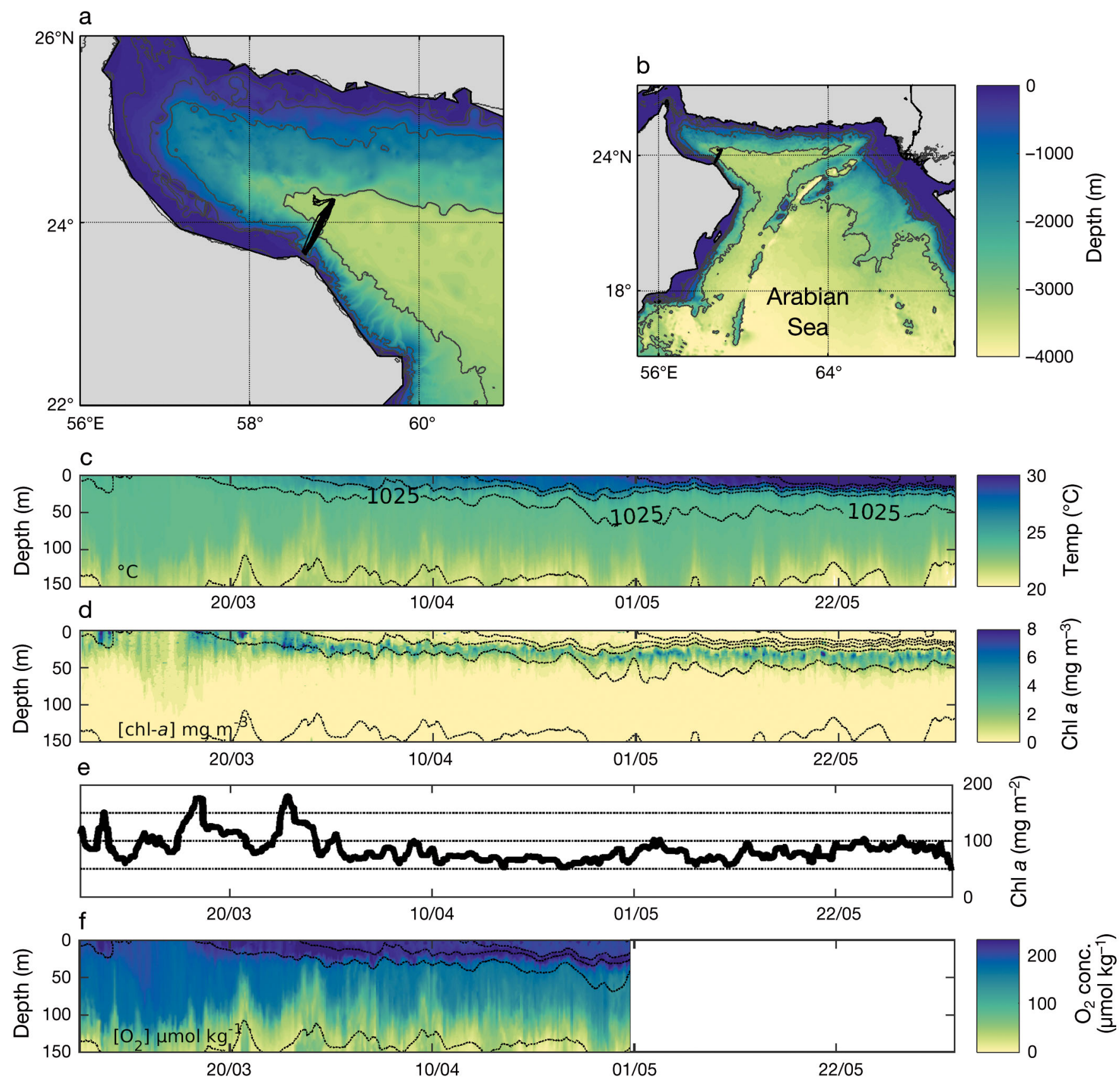

Fig. 1. (a,b) Bathymetry and Seaglider transect location (black line) in the northern Arabian Sea; bathymetry contours have been added for 100, 300, 1000 and $3000 \mathrm{~m}$ isobaths. Seaglider time series of (c) temperature $\left({ }^{\circ} \mathrm{C}\right) ;(\mathrm{d})$ chlorophyll a $(\mathrm{chl} a)$

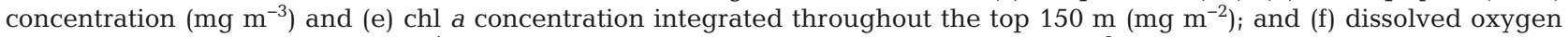
concentration $\left(\mu \mathrm{mol} \mathrm{kg}{ }^{-1}\right.$ ) overlaid with potential density contours at $0.5 \mathrm{~kg} \mathrm{~m}^{-3}$ intervals. Dates are d/mo

to excite chl a fluorescence and measure the resulting emissions in the red. Phytoplankton adapts to specific light regimes and suffers from quenching when exposed to excessive light (Biermann et al. 2015). The glider fluorescence data were first corrected for quenching using a time and depth dependent night-time ratio of optical backscatter to fluorescence corrected from the 3 channels of the ECO puck as per Hemsley et al. (2015; our Fig. 2); no quenching could be detected below the euphotic depth (1\% surface light), indicating that the process was able to accurately identify quenching-affected portions of the water column (Biermann et al. 2015). Quenchingcorrected fluorescence was then converted to chl a values using a scale factor determined by regressing the light attenuation profile from the PAR sensor to 


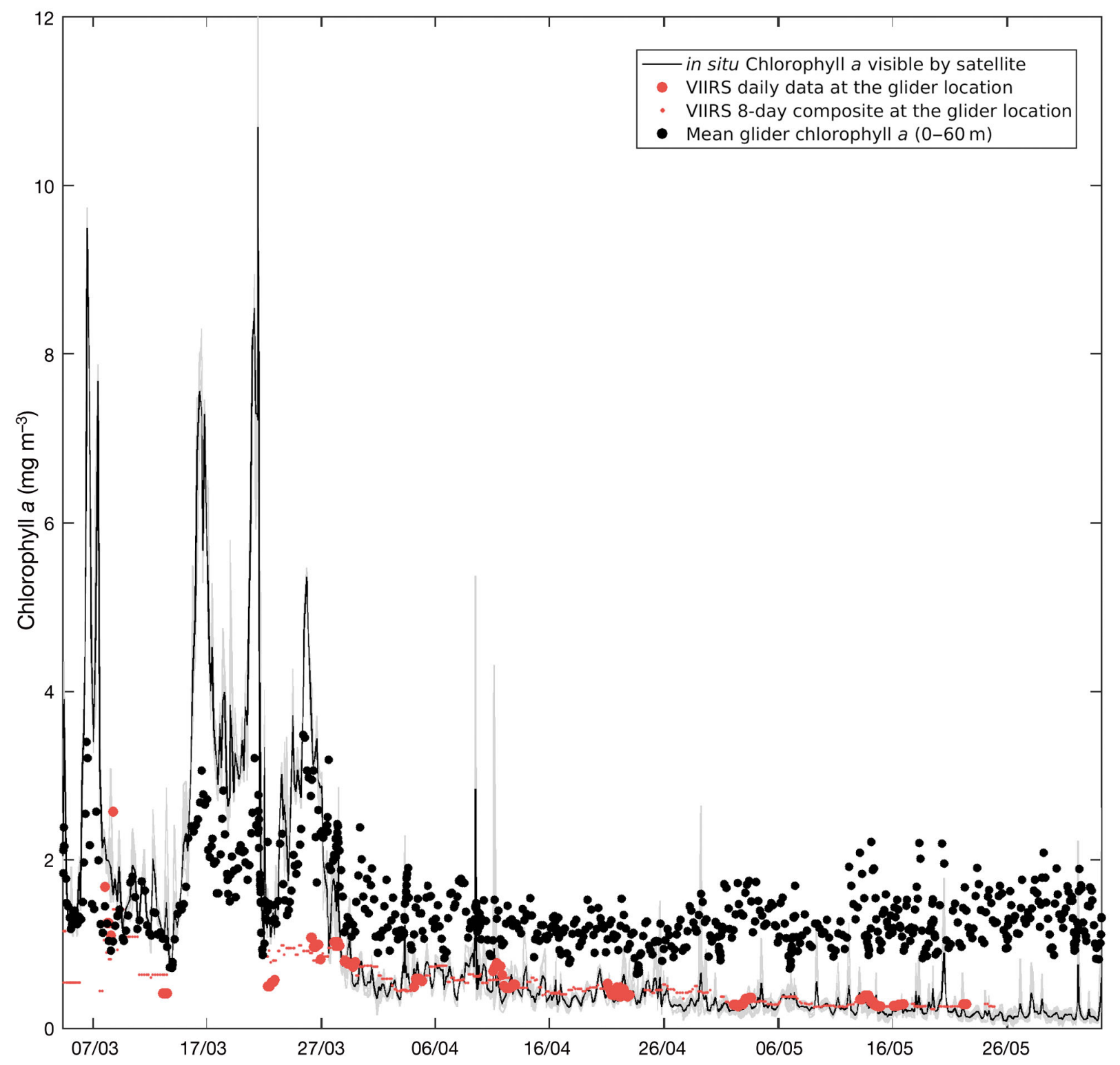

Fig. 2. Validation of the Seaglider chlorophyll a ( $\mathrm{chl}$ a) calibration. The solid black line shows the in situ optically weighted chl a measured by the glider which represents the portion of the water column visible by satellite. The black line is the mean value assuming a linear response between $400 \mathrm{~nm}$ and $700 \mathrm{~nm}$ of the PAR sensor; the gray line shows the range using wavelengths individually in $5 \mathrm{~nm}$ increments. The red markers indicate remotely sensed VIIRS chl a estimates at the Seaglider's location from daily composites (large markers) and $8 \mathrm{~d}$ composites (small markers). The black markers show the mean chl $a$ concentration in the top $60 \mathrm{~m}$ of the water column. Dates are $\mathrm{d} / \mathrm{mo}$

the theoretical light attenuation profiles calculated from the fluorescence profiles and attenuation coefficients. This same method is used for Bio-Argo floats worldwide relying on the diffuse attenuation coefficient $\left(K_{\mathrm{d}}\right)$ composed of the diffuse attenuation coefficient of pure water $\left(K_{\mathrm{w}}\right)$ and chl a component (Morel \& Maritorena 2001, Xing et al. 2011). This method relies on the assumption that there is a constant relationship between light absorbance and chl a concentration, and that the Morel \& Maritorena (2001) diffuse attenuation coefficients are representative of this region (i.e. Case I waters). The latter can be held as true in the open deep waters away from the shelf. As we observed no spatial variability in scale factors, we therefore assume the latter assumption also held true in-shore. The former assumption presents a more fundamental issue, as it is dependent both on chlorophyll packaging within cells and the ratio of phytoplankton to zooplankton. Due to the apparent shift in chlorophyll packaging observed in Noctiluca 
cells, we elected to use a single fluorescence to chl a scaling factor $(2.32 \pm 0.11)$ to avoid overestimating chl a concentrations during the latter period. To validate the calibration, we compared optically weighted chlorophyll $\left(C_{\mathrm{f}}\right)$ from the Seaglider, calculated according to the following equations, to daily $4 \mathrm{~km}$ resolution Level-3 VIIRS ocean colour products (Fig. 2; Smith et al. 2013). The Seaglider data presented a very good fit to the satellite data and are therefore comparable to the historical remotely sensed data in the region.

$$
C_{\mathrm{f}}=\frac{\int_{0}^{1 / K_{\mathrm{d}}(490 \mathrm{~nm})} C(z) f(z) \mathrm{d} z}{\int_{0}^{1 / K_{\mathrm{d}}(490 \mathrm{~nm})} f(z) \mathrm{d} z}
$$

where $C(z)$ is the chl a concentration at depth $z_{1} K_{\mathrm{d}}$ is the diffuse attenuation coefficient and $f(z)$ is given by:

$f(z)=\exp \left(-2 \int_{0}^{z} K_{\mathrm{d}}\left(490 \mathrm{~nm}, z^{\prime}\right) \mathrm{d} z^{\prime}\right)$

and $K_{\mathrm{d}}$ can be estimated using coefficients from Morel \& Maritorena (2001):

$$
K_{\mathrm{d}}(490 \mathrm{~nm})=K_{\mathrm{w}}(490 \mathrm{~nm})+\chi_{\mathrm{m}}[C h l]^{e}
$$

where $K_{\mathrm{w}}$ is the contribution of pure water and $\chi_{\mathrm{m}}[\mathrm{Chl}]^{e}$ is the term representing the biological component calculated with the Morel and Maritorena coefficients. Satellite-derived VIIRS monthly Level-3 ocean colour index products were used to map surface chl a concentrations (with a $4 \mathrm{~km}$ spatial resolution). These data were obtained from NASA's OceanColor Web, supported by the Ocean Biology Processing Group at NASA's Goddard Space Flight Center.

\section{RESULTS}

Seaglider observations captured the decline of the northeast monsoon and the spring inter-monsoon season. Initially, the Seaglider observed moderate stratification followed by a weeklong mixing event. Throughout the rest of the survey, the Seaglider recorded increasing temperatures in the upper layer of the water column (Fig. 1c) with the formation of a strong near-surface thermocline in midMarch which gradually sank to $40 \mathrm{~m}$.
Descent of the pycnocline, beginning on 20 March 2015, was accompanied by the formation of a DCM between the 1024.5 and $1025 \mathrm{~kg} \mathrm{~m}^{-3}$ isopycnals (Fig. 1d).

During the first week of the survey, chl a concentrations were uniform between the surface and $30 \mathrm{~m}$ and were the remnant of the winter algal bloom observed in February (Figs. 1, 3 \& 4). The demise of the bloom seems to have been caused by a large mixing event which distributed chl a evenly down to $110 \mathrm{~m}$ (Fig. 1d), significantly below the euphotic depth (corresponding to $1 \%$ of surface PAR; Fig. 4) over a $6 \mathrm{~d}$ period. The pre-DCM period (before 20 March 2015) shows high variability in both concentration and depth-integrated values of chl $a$. It is not known whether this variability is spatial or temporal due to the lack of remote sensing observations during this period (Fig. 2).

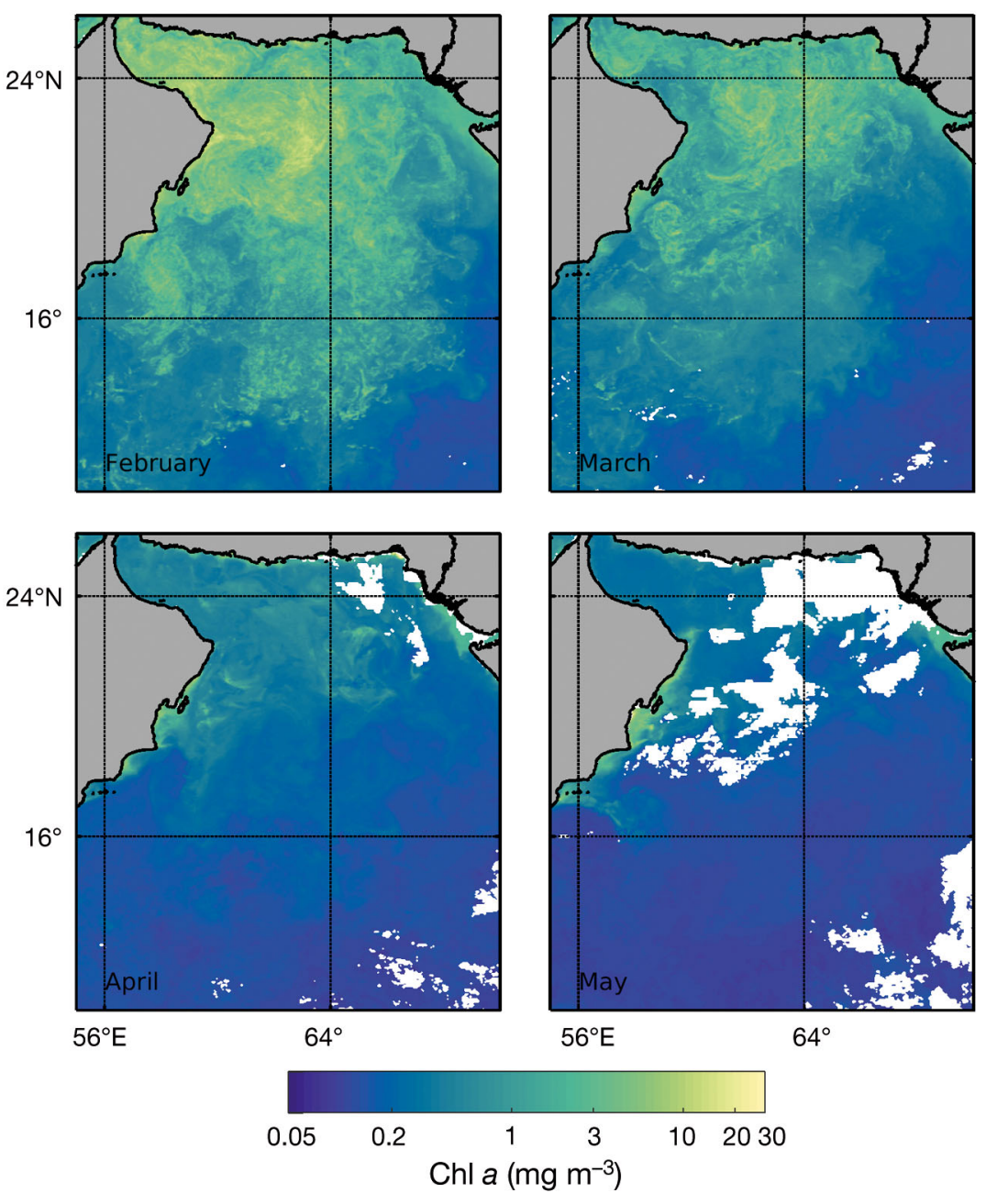

Fig. 3. Monthly chlorophyll a concentration composites from the VIIRS satellite, collected from February to May 2015. Blank regions are caused by excessive cloud cover, dust and glint 


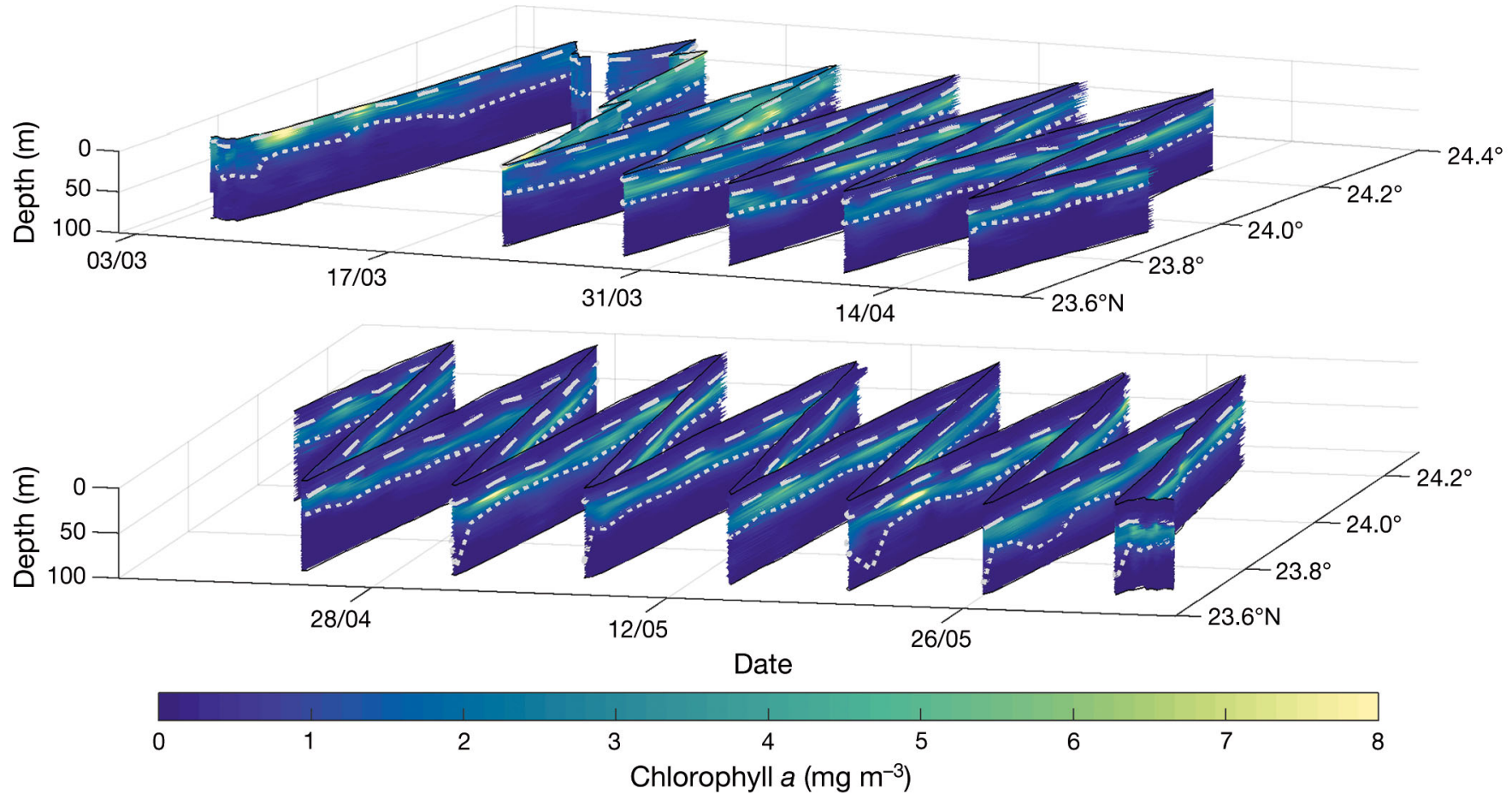

Fig. 4. Vertical distribution of chlorophyll a concentrations from Seaglider transects, against date (d/mo) and latitude, directed offshore. The first optical depth (depth to which satellites are able to see), at $490 \mathrm{~nm}$, is plotted as a dashed line, while the euphotic depth is indicated as a dotted line

As restratification occurred, a DCM formed in a thin layer $(15-30 \mathrm{~m})$. This maximum was observed through to the summer (southwest) monsoon and sustained elevated concentrations of chl a-more than half of that observed during the bloomthroughout the rest of the season (Fig. 1e). Enhanced production along the DCM is shown by an increase in dissolved oxygen concentrations along the thin layer (Fig. 1f). The DCM showed little spatial or temporal variability throughout the survey other than the gradual deepening along the pycnocline. An increase in chl a could occasionally be observed near the shelf edge but was not consistent enough to be described as a persistent feature. In particular, depth-integrated estimates of chl a showed very little variability after the collapse of the bloom and the descended thermocline (Figs. 1e \& 2).

Taxonomic analysis of Niskin samples showed that Noctiluca scintillans made up $90 \%$ of the total phytoplankton abundance as the DCM descended. The time series of processed samples illustrates a decline of Noctiluca abundance in the upper mixed layer from $\sim 120000$ to 20000 cells l$^{-1}$, from March to April 2015. This decline was accompanied by a decrease in cell diameter, from 752 to $283 \mu \mathrm{m}$. Simultaneously, the average surface area of the photosynthetic endosymbiotic flagellates Pedinomonas noctilucae inside
Noctiluca cells containing these symbionts decreased from $\sim 150000 \mu \mathrm{m}^{2}$ in December 2014 to $\sim 50000 \mu \mathrm{m}^{2}$ in April 2015 (Fig. 5). The decrease in endosymbiont size happened in proportion with the decrease in cell size leading to a constant ratio of the cell size (surface area) of the endosymbiont to that of the Noctiluca host (Fig. 5). With regard to this figure (aiming to highlight a declining trend), it should be mentioned that samples of Noctiluca (collected in December to March by Bongo nets) began well before the Seaglider campaign began, but finished once the DCM was established. No particular variability in the presence of food vacuoles was observed, with most cells containing only 1 vacuole (although in rare cases up to 5 were observed), and $<1 \%$ of cells containing food.

Phytoplankton samples at the DCM showed high diversity (Table 1); 36 species were identified in the samples collected, and were dominated by dinoflagellates. During the inter-monsoon season, the number of species declined by $\sim 50 \%$, but the total abundance of dinoflagellates did not decrease: the mean concentration remained $185000 \pm 88000$ (SD) cells $1^{-1}$ (April to May). The abundance of Noctiluca declined rapidly by the end of May. Despite the decrease in both cell size and cell abundance, this species accounted for $65-69 \%$ of the total phytoplankton biomass between April and May. 

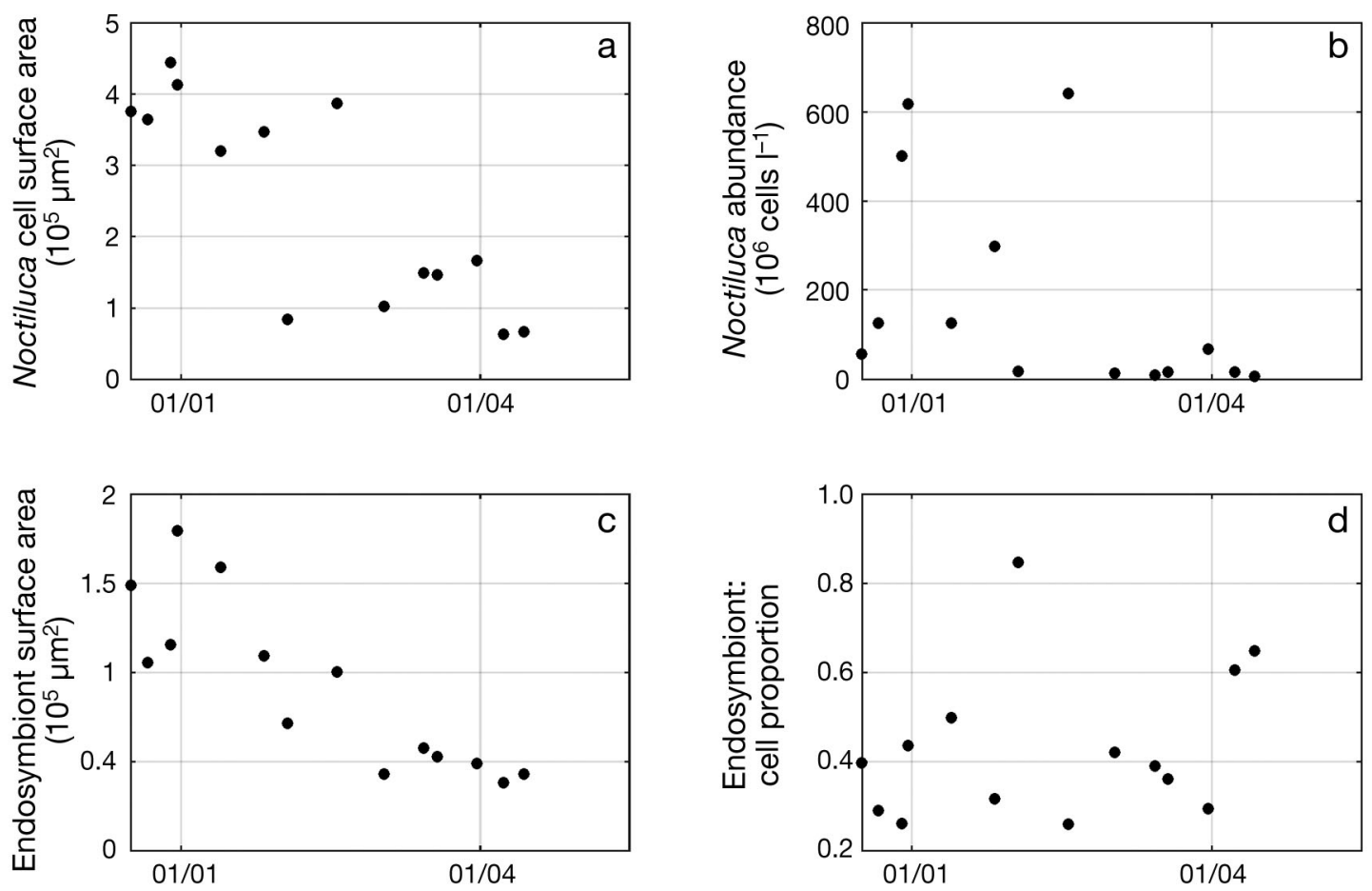

Fig. 5. Temporal changes in Noctiluca cell size and abundance, and endosymbiont size and relative proportion of endosymbiont to Noctiluca cells. Dates are d/mo

The zooplankton fraction of the plankton community inhabiting the upper mixed layer was represented by several taxonomic groups, namely Copepoda $(61 \%)$, Mollusca (9\%) Oikopleuriddae (3\%) and Cladocera (1\%), with others contributing $<1 \%$. Copepods were the most abundant group, of which 57 species were identified in the samples (Table 2). These were a mix of small-sized herbivores, carnivores and omnivores with a body length of about $1 \mathrm{~mm}$. A similar decline in species diversity was observed, with 57 species in March, 37 species in April and 19 species in June.

\section{DISCUSSION}

Although the period before the DCM (prior to 28 March 2015) showed peaks of $\sim 4 \mathrm{mg} \mathrm{m}^{-3} \mathrm{chl} \mathrm{a}$ (Fig. 2), much greater than that observed within the DCM, depth-integrated chl a values after 28 March 2015 remained elevated ( 67\% of values before 28 March; 117 versus $78 \mathrm{mg} \mathrm{m}^{-2}$ ). Considering that the spring bloom is a short-lived event whereas the DCM is persistent over several months, the contribution to the regional production budget of the DCM is potentially up to an order of magnitude greater. In particular, the proximity of the DCM to the thermocline will likely lead to a greater $f$-ratio through sub-pycnocline nutrient supply and export of organic matter below the mixed layer.

The Seaglider time series provides an interesting insight into the dynamics of the DCM in this region. It is most likely driven by exchange of nutrients across the pycnocline, fuelling production in the photic surface mixed layer while providing a measure of vertical stability near the pycnocline. Fluctuations in chl a concentration are likely to be tied to interplay between mixed layer depth and photic depth or to mixing processes regulating nutrient availability. The importance of low-mode baroclinic Rossby waves has previously been highlighted as affecting pycnocline exchanges, and could significantly influence the depth and intensity of the deep fluorescence maximum (Ravichandran et al. 2012). The dominant factor likely mediating this heterogeneity is the presence of meso- and submesoscale eddies reported in the region, and commonly observed transiting eastward along the north coast of Oman (L'Hégaret et al. 2013, Vic et al. 2015). In particular, sea surface height data imply the presence of multiple eddies in the vicinity of the glider transect. According to Tang et al. (2002), in the Arabian Sea, the chlorophyll maximum is often observed over peripheries of anticyclonic eddies and in the central 
Table 1. Taxonomic composition of the submerged algal bloom in the Gulf of Oman in April and June 2015; *sp. indicates unidentified species

\begin{tabular}{|c|c|}
\hline Class & Species \\
\hline \multicolumn{2}{|l|}{ April } \\
\hline Bacillariophyceae & Chaetoceros atlanticus \\
\hline Bacillariophyceae & Corethron criophylum \\
\hline Bacillariophyceae & Navicula sp. \\
\hline Bacillariophyceae & Nitzschia longissima \\
\hline Bacillariophyceae & Nitzschia tenuirostris \\
\hline Bacillariophyceae & Pseudo-nitzschia delicatissima \\
\hline Bacillariophyceae & Pseudo-nitzschia seriata \\
\hline Bacillariophyceae & Thalassiosira rotula \\
\hline Bacillariophyceae & Thalassiosira sp. \\
\hline Bacillariophyceae & Cyclotella caspia \\
\hline Bacillariophyceae & Skeletonema costatum \\
\hline Chrysophyceae & Dinobryon sp. \\
\hline Cryptophyceae & Rhodomonas sp. \\
\hline Cryptophyceae & ${ }^{*} \mathrm{sp}$ \\
\hline Dinophyceae & ${ }^{*} \mathrm{sp}$ \\
\hline Dinophyceae & *sp. \\
\hline Dinophyceae & ${ }^{*} \mathrm{sp}$ \\
\hline Dinophyceae & Amphydinium sp. \\
\hline Dinophyceae & Glenodinium sp. \\
\hline Dinophyceae & Gymnodinium lacustre \\
\hline Dinophyceae & Gymnodinium najadeum \\
\hline Dinophyceae & Gymnodinium simplex \\
\hline Dinophyceae & Gymnodinium sp. \\
\hline Dinophyceae & Gymnodinium wulffii \\
\hline Dinophyceae & Gyrodinium fusiforme \\
\hline Dinophyceae & Lessardia elongata \\
\hline Dinophyceae & Oxytoxum gracile \\
\hline Dinophyceae & Oxytoxum sp. \\
\hline Dinophyceae & Prorocentrum cordatum \\
\hline Dinophyceae & Prorocentrum triestinum \\
\hline Dinophyceae & Protoperidinium sp. \\
\hline Dinophyceae & Scrippsiella trochoidea \\
\hline Flagellata & *sp. \\
\hline Flagellata & ${ }^{*} \mathrm{sp}$ \\
\hline Prymnesiophyceae & Emiliania huxleyi \\
\hline Ebriophyceae & Ebria tripartita \\
\hline \multicolumn{2}{|l|}{ June } \\
\hline Bacillariophyceae & ${ }^{*} \mathrm{sp}$ \\
\hline Chrysophyceae & ${ }^{*} \mathrm{sp}$ \\
\hline Cryptophyceae & Rhodomonas sp. \\
\hline Cryptophyceae & ${ }^{*}$ sp. \\
\hline Cryptophyceae & *sp. \\
\hline Cyanophyceae & ${ }^{*} \mathrm{sp}$ \\
\hline Dinophyceae & *sp. \\
\hline Dinophyceae & Glenodinium paululum \\
\hline Dinophyceae & Gymnodinium najadeum \\
\hline Dinophyceae & Gymnodinium simplex \\
\hline Dinophyceae & Gyrodinium sp. \\
\hline Dinophyceae & Prorocentrum cordatum \\
\hline Flagellata & ${ }^{*} \mathrm{sp}$ \\
\hline Flagellata & * sp. \\
\hline Prymnesiophyceae & *sp. \\
\hline Prymnesiophyceae & Emiliania huxleyi \\
\hline
\end{tabular}

part of the cyclonic ones. Spatial shifts of eddies could therefore influence the spatial variability of chlorophyll fluorescence intensity by shifting localised regions of upwelling. This study provides an interesting contrast, as we observed little spatial heterogeneity of the DCM; no correlation was found between presence of the intermediate Persian Gulf water mass (whose position is governed by eddy dynamics; L'Hégaret et al. 2013, Vic et al. 2015) and chl a concentrations. A weak spatial signal can be observed in Fig. 4, with an intermittent increase in chl a near the shelf edge, likely linked to a strong shelf edge current providing increased shear and injection of nutrient-rich water into the photic zone.

Due to the lack of in situ calibration of the Wetlabs fluorometer, the Seaglider data can only provide a qualitative contextualisation of the observed community composition and physiological shifts in Noctiluca scintillans. However, the absence of spatial variability in the glider chl $a$, optical backscatter and oxygen supersaturation all point to a homogeneity of the DCM across the entire survey region (Figs. $1 \& 4$ ). Nevertheless, it is important to keep in mind that without in situ validation, it is not possible to assess whether the strong chl $a$ at depth is linked to an increase in autotrophic biomass or increased packaging of pigment at depth relative to surface phytoplankton (Cullen 2015). It is generally understood that the density of the endosymbiont Pedinomonas noctilucae scales with cell size in Noctiluca species within a given established community (Sriwoon et al. 2008). In this study, we characterised endosymbiont density as the average endosymbiont algae surface area inside Noctiluca cells. During this study, both the size of Noctiluca cells and endosymbiont surface area declined, from the late northeast monsoon to the inter-monsoon season (with no apparent change in proportion). It is possible that through low-light adaptation there may be a reduction in the carbon to chl a ratio. We suspect that such adaptation would have led to an increase in endosymbiont density within the Noctiluca cells; however, we observed no such change, only a decrease in cell size, possibly indicating a shift away from heterotrophy and a reduced need for motility within the water column (Fig. 5). The endosymbiont density is an ecologically important characteristic of the Noctiluca population, which can grow photoautotrophically without external food particles for generations (Furuya et al. 2006, Saito et al. 2006). In our observations, the number of food vacuoles as well as their saturation with food particles was low, thereby also indicating a shift towards autotrophy by the end of the inter-monsoon 
Table 2. Taxonomic composition of Copepoda in the Gulf of Oman in March, April and June 2015

\begin{tabular}{|c|c|c|}
\hline March & April & June \\
\hline Canthocalanus pauper & Canthocalanus pauper & Nannocalanus minor \\
\hline Cosmocalanus darwinii & Acrocalanus longicornis & Acrocalanus longicornis \\
\hline Nannocalanus minor & Calocalanus plumulosus & Paracalanus spp. \\
\hline Acrocalanus spp. & Paracalanus spp. & Paracalanus indicus \\
\hline Acrocalanus longicornis & Paracalanus indicus & Paracalanus tropicus \\
\hline Acrocalanus gracilis & Paracalanus tropicus & Paracalanus aculeatus minor \\
\hline Acrocalanus gibber & Paracalanus aculeatus & Paracalanus denudatus \\
\hline Calocalanus spp. & Paracalanus denudatus & Parvocalanus elegans \\
\hline Calocalanus plumulosus & Parvocalanus spp. & Clausocalanus spp. \\
\hline Paracalanus spp. & Parvocalanus elegans & Clausocalanus furcatus \\
\hline Paracalanus indicus & Subeucalanus pileatus & Euchaeta spp. \\
\hline Paracalanus tropicus & Clausocalanus farrani & Temora turbinata \\
\hline Paracalanus aculeatus minor & Clausocalanus furcatus & Oncaea clevei \\
\hline Paracalanus aculeatus & Clausocalanus minor & Oncaea venusta \\
\hline Paracalanus denudatus & Euchaeta spp. & Clytemnestra spp. \\
\hline Parvocalanus spp. & Euchaeta indica & Corycaeus spp. \\
\hline Parvocalanus elegans & Temora turbinata & Corycaeus agilis \\
\hline Subeucalanus pileatus & Candacia spp. & Farranula spp. \\
\hline Subeucalanus subcrassus & Oithona spp. & Farranula gibbula \\
\hline Subeucalanus crassus & Oithona nana & \\
\hline Clausocalanus spp. & Oithona brevicornis & \\
\hline Clausocalanus farrani & Oithona plumifera & \\
\hline Clausocalanus furcatus & Oithona fallax & \\
\hline Clausocalanus minor & Euterpina acutifrons & \\
\hline Euchaeta spp. & Oncaea venusta & \\
\hline Euchaeta indica & Copilia mirabilis & \\
\hline Centropages spp. & Corycaeus spp. & \\
\hline Centropages tenuiremis & Corycaeus lubbocki & \\
\hline Centropages orsinii & Corycaeus agilis & \\
\hline Pseudodiaptomus spp. & Corycaeus pumilus & \\
\hline Pseudodiaptomus serricaudatus & Corycaeus erythraeus & \\
\hline Pseudodiaptomus arabicus & Corycaeus pacificus & \\
\hline Temora turbinata & Farranula gibbula & \\
\hline \multicolumn{3}{|l|}{ Candacia spp. } \\
\hline \multicolumn{3}{|l|}{ Candacia curta } \\
\hline \multicolumn{3}{|l|}{ Labidocera acuta } \\
\hline \multicolumn{3}{|l|}{ Acartia plumosa } \\
\hline \multicolumn{3}{|l|}{ Acartia amboinensis } \\
\hline \multicolumn{3}{|l|}{ Oithona spp. } \\
\hline \multicolumn{3}{|l|}{ Oithona nana } \\
\hline \multicolumn{3}{|l|}{ Oithona brevicornis } \\
\hline \multicolumn{3}{|l|}{ Oithona plumifera } \\
\hline \multicolumn{3}{|l|}{ Oithona setigera } \\
\hline \multicolumn{3}{|l|}{ Oithona fallax } \\
\hline \multicolumn{3}{|l|}{ Euterpina acutifrons } \\
\hline \multicolumn{3}{|l|}{ Oncaea clevei } \\
\hline \multicolumn{3}{|l|}{ Oncaea venusta } \\
\hline \multicolumn{3}{|l|}{ Sapphirina spp. } \\
\hline \multicolumn{3}{|l|}{ Copilia mirabilis } \\
\hline \multicolumn{3}{|l|}{ Macrosetella gracilis } \\
\hline \multicolumn{3}{|l|}{ Corycaeus spp. } \\
\hline \multicolumn{3}{|l|}{ Corycaeus lubbocki } \\
\hline Corycaeus agilis & & \\
\hline Corycaeus pumilus & & \\
\hline Corycaeus erythraeus & & \\
\hline Corycaeus crassiusculus & & \\
\hline Farranula spp. & & \\
\hline
\end{tabular}


season. This is supported by the elevated oxygen concentration along the DCM, indicative of elevated production (Fig. 1).

The algal blooms observed in the northern Arabian Sea are predominantly formed by Noctiluca species, and accompanied by less abundant diatoms of the genera Rhizosolenia, Thalassionema and Chaetoceros (Madhu et al. 2012). A Noctiluca bloom sampled along the southwest coast of India in March 2007 was accompanied by 9 species of diatoms (namely $C$. brevis, C. didymus, Navicula digio-radiata, N. elegens, N. lyra, $R$. alata, $R$. hebetata, $R$. imbricata, $T$. nitzschioides) and 10 species of dinoflagellates (Ceratium furca, C. trichoceros, C. vultur, Diplopeltopsis minor, Diplopsalis lenticula, Prorocentrum micams, Protoperidinium obovatum, P. oceanicum, P. pyriforme and P. steneii; Padmakumar et al. 2010). In our case, the number of phytoplankton species accompanying the Noctiluca bloom was twice as high as that recorded in the 2007 survey (Table 1). Perhaps this difference is associated with a basin-scale phytoplankton diversity pattern which is high in the western part of the Arabian Sea compared to its central and eastern parts.

The 'paradox of mesozooplankton biomass' reported for the western and eastern Arabian Sea (Madhupratap et al. 1992, 1996, Baars 1999, Piontkovski et al. 2015) is based on observations that biomass varies little throughout the seasons. Our observations of a persistent DCM, with a decline in species diversity and a decline in chlorophyll content of Noctiluca cells, could shed some light on this paradox. We speculate that the persistent subsurface algal bloom acts as a food source for mesozooplankton organisms, many of which migrate diurnally through the bloom. In combination with changes in food preference including consumption of microbial organisms (Smith \& Madhupratap 2005), this might keep the biomass stable over multiple seasons.

As a direct result of the limited number of in situ observations, most estimates of production in the region have relied on remote sensing. The presence of a persistent DCM has important implications for the estimation of chlorophyll concentrations from remote sensing in the Arabian Sea. Fig. 3 is a monthly composite of chl a distribution as estimated via remote sensing within the Gulf of Oman and northwestern Arabian Sea. One can see that the month of April, for instance, is characterised by minimal concentrations. However, the glider time series indicated the presence of a deep maximum during this time. The issue of satellites not being able to observe features below the first optical depth is well understood and clearly impacts past assessments of the region (Figs. 2 \& 4). It is also likely that this bias is applicable to the wider Arabian Sea, as similar deep fluorescence maxima have been observed beyond the Gulf (Barlow et al. 1999, Ravichandran et al. 2012).

Assessments of primary production relying solely on remote sensing observations may significantly underestimate chl a biomass during the inter-monsoon periods. Studies of DCM worldwide have shown that this layer can contribute significantly to the primary production of a region (Anderson 1969, Shulenberger \& Reid 1981, Cullen 2015, Queste et al. 2016). The persistence of Noctiluca-dominated subsurface algal blooms and physiological change as the DCM descends have yet to be studied in detail. Due to their mixotrophic nature, it is possible that Noctilucadominated DCM may exhibit a higher carbon to chlorophyll ratio than those traditionally observed worldwide. This emphasises the importance of properly qualifying the phenology, distribution and intensity of this Noctiluca-dominated DCM due to its critical role as the basis of the regional food web, sustaining large and important fisheries locally, and in carbon export, influencing both carbon sequestration and the oxygen consumption potential of the strong oxygen minimum zone present in the Gulf and Arabian Sea.

\section{CONCLUSIONS}

The Seagliders launched in the northwestern Arabian Sea provided valuable insights into the processes occurring during the collapse of the bloom and the formation of the DCM during the spring intermonsoon season. This dataset provides the first set of high-resolution observations describing the spatial and temporal variability of the DCM. We observed little spatial variability in depth and extent of the DCM, indicating that this process is widespread across at least a large part of the basin. Plankton samples indicated a community dominated by Noctiluca scintillans throughout the spring inter-monsoon season, which we suggest acted as seed stock for the summer bloom trigged by the mixing and subsequent injection of nutrients into the upper layer, induced by the summer (southwest) monsoon. Species diversity of the subsurface algal bloom exhibited the 2 -fold decrease during the spring inter-monsoon period.

Most estimates of regional productivity in the region are currently based on remote sensing; this method has well-understood limitations that risk underesti- 
mating production in regions with strong DCM. Our measurements showed a strong DCM below the first optical depth. As this subsurface bloom persisted throughout the inter-monsoon season and was spatially homogeneous, it potentially represents a very significant carbon sink that has yet to be accurately quantified through its potentially greater $f$-ratio and elevated autotrophic biomass. We suggest that this region of the Arabian Sea is much more productive than previously estimated.

Despite its limitations, remote sensing has formed the basis of our understanding of the region for many years, due to issues of inaccessibility. With the advent of new autonomous platforms such as Seagliders, we can now complement remote sensing observations with cross-calibrated, in situ high sub-surface measurements to expand our understanding of remote regions.

Acknowledgements. This work was supported by the ONR GLOBAL grant N62909-14-1-N224/SQU, grant EG/AGR/ FISH/14/01 and UK NERC Grants NE/M005801/1 and NE/ N012658/1. We thank L. Galkovskaya for technical assistance with mapping parameters over transects. We also acknowledge the reviewers' careful comments which greatly improved the manuscript.

\section{LITERATURE CITED}

Al-Azri A, Al-Hashmi K, Goes J, Gomes H and others (2007) Seasonality of the bloom-forming heterotrophic dinoflagellate Noctiluca scintillans in the Gulf of Oman in relation to environmental conditions. Int $\mathrm{J}$ Oceans Oceanogr 2:51-60

Al-Hashmi K, Smith S, Claereboudt M, Piontkovski SA, AlAzri A (2015) Dynamics of potentially harmful phytoplankton in a semi enclosed bay in the Sea of Oman. Bull Mar Sci 91:141-166

* Anderson GC (1969) Subsurface chlorophyll maximum in the northeast Pacific Ocean. Limnol Oceanogr 14:386-391

Baars MA (1999) On the paradox of high mesozooplankton biomass, throughout the year in the western Arabian Sea: re-analysis of IIOE data and comparison with newer data. Indian J Mar Sci 28:125-137

Barlow RG, Mantoura RFC, Cummings DG (1999) Monsoonal influence on the distribution of phytoplankton pigments in the Arabian Sea. Deep-Sea Res II 46:677-699

Biermann L, Guinet C, Bester M, Brierley A, Boehme L (2015) An alternative method for correcting fluorescence quenching. Ocean Sci 11:83-91

Chaghtai F, Saifullah SM (2006) On the occurrence of green Noctiluca scintillans blooms in coastal waters of Pakistan, North Arabian Sea. Pak J Bot 38:893-898

Cullen JJ (2015) Subsurface chlorophyll maximum layers: enduring enigma or mystery solved? Annu Rev Mar Sci 7:207-239

Dwivedi RM, Chauhan R, Solanki HU, Raman M, Matondkar SGP, Madhu VR, Meenakumari B (2012) Study of ecological consequence of the bloom (Noctiluca miliaris) in off shore waters of the Northern Arabian Sea. Indian J Geo Mar Sci 41:304-313

* Eriksen CC, Osse TJ, Light RD, Wen T and others (2001) Seaglider: a long-range autonomous underwater vehicle for oceanographic research. IEEE J Ocean Eng 26: 424-436

F Furuya K, Saito H, Sriwoon R, Omura T, Furio EF, Borja VM, Lirdwitayaprasit T (2006) Vegetative growth of Noctiluca scintillans with green flagellate endosymbiont Padinomonas noctilucae. Afr J Mar Sci 28:305-308

* Gomes HR, Goes JI, Matondkar SCP, Parab SG, Al-Azri ARN, Thoppil PG (2008) Blooms of Noctiluca miliaris in the Arabian Sea - an in situ and satellite study. DeepSea Res I 55:751-765

Harrison PJ, Furuya K, Glibert PM, Xu J and others (2011) Geographical distribution of red and green Noctiluca scintillans. Chin J Oceanology Limnol 29:807-831

*Hemsley VS, Smyth TJ, Martin AP, Frajka-Williams E, Thompson AF, Damerell G, Painter SC (2015) Estimating oceanic primary production using vertical irradiance and chlorophyll profiles from ocean gliders in the North Atlantic. Environ Sci Technol 49:11612-11621

* Lévy M, Shankar D, André JM, Shenoi SSC, Durand F, Montégut CDB (2007) Basin-wide seasonal evolution of the Indian Ocean's phytoplankton blooms. J Geophys Res 112:C12014

*L'Hégaret P, Lacour L, Carton X, Roullet G, Baraille R, Corréard S (2013) A seasonal dipolar eddy near Ras al Hamra (Sea of Oman). Ocean Dyn 63:633-659

* Madhu NV, Jyothibabu R, Maheswaran PA, Jayaraj KA, Achuthankutty CT (2012) Enhanced chlorophyll $a$ and primary production in the northern Arabian Sea during the spring intermonsoon due to green Noctiluca scintillans bloom. Mar Biol Res 8:182-188

Madhupratap M, Haridas P, Ramaiah N, Achuthankutty CT (1992) Zooplankton of southwest coast of India: abundance, composition, temporal and spatial variability in 1987. In: Desai BN (ed) Oceanography of Indian Ocean. Oxford \& IBH, New Delhi, p 99-112

Madhupratap M, Gopalakrishnan TC, Haridas P, Nair KKC, Aravindakshan PN, Padmavati G, Paul S (1996) Lack of seasonal and geographic variation in mesozooplankton biomass in the Arabian Sea and its structure in the mixed layer. Curr Sci 71:863-868

* Morel A, Maritorena S (2001) Bio-optical properties of oceanic waters - a reappraisal. J Geophys Res 106: 7163-7180

Padmakumar KB, Sreerenjima G, Fanimol CL, Sanjeevan VN (2010) Preponderance of heterotrophic Noctiluca scintillans during a multispecies diatom bloom along the southwest coast of India. Int J Oceans Oceanogr 4:55-63

Piontkovski SA, Claereboudt MR (2012) Interannual changes of the Arabian Sea productivity. Mar Biol Res 8: 189-194

พ Piontkovski SA, Al-Mawali A, Al-Kharusi A, Al-Manthri W, Smith S, Popova E (2015) Mesozooplankton of the Omani shelf: taxonomy, seasonality and spatial distribution. Int Aquat Res 7:301-314

Queste BY (2014) Hydrographic observations of oxygen and related physical variables in the North Sea and Western Ross Sea Polynya. PhD thesis, University of East Anglia, Norwich

Queste BY, Fernand L, Jickells TD, Heywood KJ, Hind AJ (2016) Drivers of summer oxygen depletion in the central North Sea. Biogeosciences 13:1209-1222 
Ravichandran M, Girishkumar MS, Riser S (2012) Observed variability of chlorophyll a using Argo profiling floats in the southeastern Arabian Sea. Deep-Sea Res I 65:15-25

Saba VS, Friedrichs MAM, Antoine D, Armstrong RA and others (2011) An evaluation of ocean color model estimates of marine primary productivity in coastal and pelagic regions across the globe. Biogeosciences 8:489-503

Saito H, Furuaya K, Lirdwitayaprasit T (2006) Photoautotrophic growth of Noctiluca scintillans with an endosymbiont Pedinomonas noctilucae. Plankton Benthos Res 1: 97-101

Sawant S, Madhupratap M (1996) Seasonality and composition of phytoplankton in the Arabian Sea. Curr Sci 71: 869-873

Shulenberger E, Reid JL (1981) The Pacific shallow oxygen maximum, deep chlorophyll maximum, and primary productivity, reconsidered. Deep-Sea Res 28:901-919

Smith ME, Bernard S, O'Donoghue S (2013) The assessment of optimal MERIS ocean colour products in the shelf waters of the KwaZulu-Natal Bight, South Africa. Remote Sens Environ 137:124-138

Smith SL, Madhupratap M (2005) Mesozooplankton of the Arabian Sea: patterns influenced by seasons, upwelling and oxygen concentrations. Prog Oceanogr 65:214-239

Editorial responsibility: Katherine Richardson, Copenhagen, Denmark
Sriwoon R, Pholpunthin P, Lirdwitayaprasit T, Kishino M, Furuya K (2008) Population dynamics of green Noctiluca scintillans (Dinophyceae) associated with the monsoon cycle in the upper Gulf of Thailand. J Phycol 44:605-615

* Tang DL, Kawamura H, Luis A (2002) Short-term variability of phytoplankton blooms associated with a cold eddy in the northwestern Arabian Sea. Remote Sens Environ 81: 82-89

*Thibodeau PS, Roasler CS, Drapeau SL, Matondkar SGP, Goes JI, Werdell PJ (2014) Locating Noctiluca miliaris in the Arabian Sea: an optical proxy approach. Limnol Oceanogr 59:2042-2056

* Vic C, Roullet G, Capet X, Carton X, Molemaker MJ, Gula J (2015) Eddy topography interactions and the fate of the Persian Gulf Outflow. J Geophys Res 120:6700-6717

* Wiggert JD, Hood RP, Banse K, Kindle JC (2005) Monsoondriven biogeochemical processes in the Arabian Sea. Prog Oceanogr 65:176-213

Xing X, Morel A, Claustre H, Antoine D, D'Ortenzio F, Poteau A, Mignot A (2011) Combined processing and mutual interpretation of radiometry and fluorimetry from autonomous profiling Bio Argo floats: chlorophyll a retrieval. J Geophys Res 116:C06020

Submitted: April 14, 2016; Accepted: November 17, 2016 Proofs received from author(s): February 15, 2017 